\title{
Coffee industry waste-derived biochar: characterization and agricultural use evaluation according to Brazilian legislation
}

\author{
Ruan Carnier $^{1}$ (iD), Aline Renee Coscione ${ }^{2, *}$ (D), Douglas Delaqua ${ }^{1}$ (D), Cleide Aparecida de Abreu² (D) \\ 1. Instituto Agronômico - Programa de Pós-Graduação em Agricultura Tropical e Subtropical - Gestão de Recursos Agroambientais - Campinas \\ (SP), Brazil. \\ 2. Instituto Agronômico - Centro de Solos e Recursos Ambientais - Campinas (SP), Brazil. \\ Received: June 3, 2021 | Accepted: Sep. 13, 2021 \\ Section Editor: Gabriel Constantino Blain \\ *Corresponding author: aline.coscione@sp.gov.br \\ How to cite: Carnier, R., Coscione, A. R., Delaqua, D. and Abreu, C. A. (2021). Coffee industry waste-derived biochar: characterization and \\ agricultural use evaluation according to Brazilian legislation. Bragantia, 80, e5721. https://doi.org/10.1590/1678-4499.20210159
}

\begin{abstract}
The agricultural use of biochar has been the focus of much research in the last decade due to the improvement of soil chemical, physical, and biological attributes. Nonetheless, Brazil still has no specific legislation for biochar, limiting its agricultural use. The objective of the present work is to evaluate the use of biochar produced from spent coffee grounds (SCG) and coffee parchment (CP) by slow pyrolysis at $700{ }^{\circ} \mathrm{C}$ according to the existing framework of the Brazilian Ministry of Agriculture, Livestock, and Food Supply (MAPA) legislation for organic fertilizer, soil conditioner or plant substrate. Biochar was characterized according to normative instructions No. 17, 31, 61, 7, 5 and 35. Although not required by the addressed legislation, the semitotal content of macro- and micronutrients was also determined. While CP biochar could be used as an organic fertilizer or plant substrate, SCG biochar, due to its higher Ni content and lower than required cation exchange capacity (CEC), did not meet MAPA legislation criteria to allow for its agricultural use. Future regulations can be based on the current standards, and structural attributes, such as total C content, particle size distribution, and complete macroand micronutrient determination should be included. Further research may also indicate the viability of biochar use as a soil conditioner based on a more representative set of biomasses with a higher CEC. These considerations will help to take advantage of the benefits of biochar to soil, contributing to a circular economy, which is still at a difficult stage in Brazil.
\end{abstract}

Key words: coffee wastes, physicochemical characterization, soil conditioner, plant substrate, organic fertilizer.

\section{INTRODUCTION}

Biochar is a product originating from thermochemical processes, which include pyrolysis, torrefaction, hydrothermal carbonization and gasification (Jeyasubramanian et al. 2021). Pyrolysis is the most popular technique and is performed under conditions where oxygen is totally or partially absent, with minimum liberation of $\mathrm{CO} 2$ and other gases (both condensable and non-condensable) to the atmosphere (Lehmann and Joseph 2015). The pyrolysis process is generally carried out in ovens and reactors, which have been specifically designed for biochar production (Lin et al. 2017) or in low-cost kilns that can be adapted for in situ biochar production for farmers (Cornelissen et al. 2016). Pyrolysis is generally performed at temperatures between 350 and $800{ }^{\circ} \mathrm{C}$, and when performed slowly, the residence time of the biomass in the oven ranges from minutes to hours (Hussain et al. 2017). The reactor temperature choice depends on the intended use of the biochar, and different pyrolysis protocols have significant impacts on the properties of the resultant biochar, such as $\mathrm{pH}$ and surface area, as well as yield (Shaaban et al. 2013; Zhao et al. 2018).

Biochar can be produced from a wide range of biomasses (agricultural residues, forest/wood biomass, aquatic biomass, urban/industrial waste, animal manure, and sewage sludge) (Gabhane et al. 2020). However, there are important parameters to consider in the choice of feedstock. Ideally, biomasses for which there are not yet well-defined destinations that have 
no aggregated agricultural value and are produced in large quantities should be chosen. These criteria are met by some residues from the processing procedure for coffee beans. Brazil is the largest producer and exporter of coffee in the world, contributing, on average, to $25.4 \%$ of global coffee exportation, and its total coffee production for 2020 was 63.1 million bags of beans (Conab 2020). Coffee processing generates large quantities of residues, approximately $1.1 \mathrm{t}$.ton ${ }^{-1}$ of coffee beans (Dias et al. 2014). Consequently, Brazil has an abundance of coffee-processing-derived biomass residues, which could serve as feedstock for biochar production. Among these residues, the use of coffee parchment as a plant substrate has been reported in the literature (Soulaïmana et al. 2019), although studies related to this biomass are rare. The agricultural use of spent coffee grounds has also been reported, for example, as fertilizer (Cervera-Mata et al. 2019). Nevertheless, low agricultural efficiency or even a potential phytotoxic effect has been reported when spent coffee grounds are used in their raw form in soils (Carnier et al. 2019; Hardgrove and Livesley 2016). Thus, the conversion of these residues to biochar could be an effective alternative.

Biochar can be employed in agriculture as fertilizers (Kamau et al. 2019), mixed with mineral (NPK) fertilizers (Magalhães et al. 2018), used as soil conditioners (Silva et al. 2018), and employed as a substrate for growing plants (Dispenza et al. 2016). Martins Filho et al. (2020) and Silva et al. (2021) also demonstrated the impact of coffee waste biochar on soil attributes, which provided an increase in nutrients and improved biological activity. Beyond these agricultural uses, important environmental applications have been shown for biochar, including increasing carbon stocks in soils, mitigating the greenhouse effect (Liu et al. 2019), and remediating environments contaminated by heavy metals (Chwastowski et al. 2020; Manzano et al. 2020).

The commercialization of biochar for agricultural use has already commenced in a number of countries under various trade names and for a variety of uses (fertilizers, soil conditioner, and plant substrate). A key contributing factor to the international acceptance of biochar for use in agriculture has been the existence of specific protocols for their characterization, developed by the International Biochar Initiative (IBI 2015) and the European Biochar Certificate (EBC 2012). Both the IBI and the $\mathrm{EBC}$ are nongovernmental entities whose objectives are the sustainable production and appropriate agricultural utilization of biochar without risk to the environment or agricultural systems. These international protocols establish definitions for biochar materials and describe standardized testing and measurement methods for the determination of selected physicochemical properties. In addition to the IBI and EBC protocols, a book entitled Biochar: A Guide to Analytical Methods was launched in 2017, which comprises a detailed manual of analytical methods specific to biochar (Singh et al. 2017).

The current situation in Brazil is that for a biochar to be used directly in agriculture or commercialized, it must satisfy the directives proposed within the series of normative instructions (NIs) issued by the Brazilian Ministry of Agriculture, Livestock, and Food Supply (MAPA). These normative practices include soil conditioners (Brazil 2006; 2007; 2008), plant substrates (Brazil 2007; 2008; 2016a), and organic fertilizers (Brazil; 2016b; 2020). Despite the great agricultural and economic potential of biochar, its unique physicochemical characteristics could preclude its adequacy to the current legislation and consequently its commercialization and safe use by various sectors of Brazilian agriculture, failing to contribute to the circular economy.

Given these considerations and the lack of studies that evaluate the agricultural use of biochar in Brazil in the legal scope, in the present work, two biochars agricultural potential produced from coffee wastes were evaluated, according to the current Brazilian legislation based on its overall characterization.

\section{MATERIAL AND METHODS}

Spent coffee grounds (SCG) and coffee parchment (CP) were selected as feedstocks from the coffee industry due to their contrasting characteristics and misuse or difficult final disposal. Both materials were air dried, and their original particle size distribution was maintained. After drying, these residues were pyrolyzed under a $\mathrm{N} 2$ atmosphere in a reactor of continuous operation with a production capacity of $2 \mathrm{t} \cdot \mathrm{day}^{-1}$ at a heating rate of $5{ }^{\circ} \mathrm{C} \cdot \mathrm{min}^{-1}$ up to $700{ }^{\circ} \mathrm{C}$ and a residence time of $1 \mathrm{~h}$, followed by slow cooling to room temperature. A batch was produced for each biochar, which was homogenized, and then samples were collected for characterization without any further preparation step. 
The biochar was characterized according to the requirements of the normative instructions from MAPA applicable to substrates, organic fertilizers and soil conditioners (Table 1). The NI No. 61 (Brazil 2020) specifies the guarantees and tolerances for organic fertilizers destined for agricultural use. The NI No. 61 (Brazil 2020) also classifies organic fertilizers in classes A (without sanitary waste) and B (with sanitary waste, authorized by the environmental agency), ensuring safe agricultural use. Normative instruction No. 35 (Brazil 2008) specifies the guarantees and tolerances for the soil conditioner, NI No. 5 (Brazil 2016a) includes the classification, specification, guarantees and tolerances for the plant substrate, and NI No. 7 (Brazil 2016b) specifies the maximum limits of contaminants for organic fertilizers, soil conditioner and plant substrate.

Table 1. Physical-chemical attributes performed for both studied biochars and the specifications required by the Brazilian legislation from MAPA.

\begin{tabular}{|c|c|c|c|c|c|}
\hline \multirow{3}{*}{ Parameter } & \multirow{2}{*}{ NI No. 61} & \multirow{2}{*}{ NI No. 35} & \multirow{2}{*}{ NI No. 5} & \multicolumn{2}{|c|}{ NI No. 7} \\
\hline & & & & ${ }^{1} \mathbf{A}$ & ${ }^{1} \mathrm{~B}$ \\
\hline & \multicolumn{5}{|c|}{ Value declaration/permitted values } \\
\hline Moisture & Max: $40 \%$ & - & VD & - & - \\
\hline $\mathrm{pH}$ & VD & - & VD & - & - \\
\hline $\mathrm{N}$ & Min: $0.5 \%$ & - & - & - & - \\
\hline OC & Min: $15 \%$ & - & - & - & - \\
\hline CEC & VD & Min: $200 \mathrm{mmol}_{\mathrm{c}} \cdot \mathrm{kg}^{-1}$ & - & - & - \\
\hline CEC/OC & VD & - & - & - & - \\
\hline EC & - & - & VD & - & - \\
\hline Bulk density & - & - & VD & - & - \\
\hline WHC & - & Min: 60\% & VD & - & - \\
\hline Particle size distribution & - & - & - & - & - \\
\hline Macro- and micronutrients & - & - & - & - & - \\
\hline As & - & - & - & 20 & 20 \\
\hline $\mathrm{Cd}$ & - & - & - & 3.0 & 8.0 \\
\hline $\mathrm{Pb}$ & - & - & - & 150 & 300 \\
\hline $\mathrm{Cr}$ & - & - & - & 22.0 & 3500 \\
\hline $\mathrm{Hg}$ & - & - & - & 1.0 & 2.5 \\
\hline $\mathrm{Ni}$ & - & - & - & 70 & 175 \\
\hline $\mathrm{Se}$ & - & - & - & 80 & 80 \\
\hline Glass, plastics and metals & - & - & - & ${ }^{4} 0.5 \%$ & - \\
\hline Stones & - & - & - & ${ }^{4} 5.0 \%$ & - \\
\hline
\end{tabular}

$\mathrm{VD}=$ value declaration; $\mathrm{NI}=$ normative instruction; $\mathrm{As}=$ arsenic $\mathrm{Cd}=$ cadmium; $\mathrm{Pb}=$ lead; $\mathrm{Cr}=$ chromium; $\mathrm{Hg}=\mathrm{mercury} ; \mathrm{Ni}=$ nickel; Se = selenium; $\mathrm{N}=$ nitrogen; $\mathrm{CEC}=$ cation exchange capacity; $\mathrm{EC}=$ electrical conductivity; $\mathrm{WHC}=$ water holding capacity.

Note. Max = maximum; Min = minimum; - Not required. ${ }^{1}$ Metals: maximum allowed value in $\mathrm{mg} \cdot \mathrm{kg}^{-1}$ for organic fertilizers and soil conditioner (A) and plant substrate (B). ${ }^{2}$ Limit for hexavalent chromium. ${ }^{3}$ Limit for total chromium. ${ }^{4}$ Limit for inert materials: maximum value in dry mass.

Analyses performed: moisture and $\mathrm{pH}$ (water) (Brazil 2017), $\mathrm{pH}\left(\mathrm{CaCl}_{2}\right)$ and electrical conductivity (EC) (Brazil 2007); organic carbon (OC) and total nitrogen (N) were described by Nelson and Sommers (1996) and Brazil (2017), respectively, and cation exchange capacities (CECs) were determined according to Brazil (2007); potentially toxic metals were determined by method 3051A from U.S. EPA (2007) (Brazil 2016b), except hexavalent chromium (Cr6+), which was obtained according to Sá et al. (2021). The inert materials were determined as described by Brazil (2017), and the water holding capacity (WHC) and bulk (volumetric) density were determined according to Brazil (2008). The particle size distribution analysis was obtained as described in Brazil (2020). Although not required by the legislation addressed, the determination of the semitotal content of macronutrients (calcium [Ca], potassium $[\mathrm{K}]$, magnesium $[\mathrm{Mg}]$, and sulfur $[\mathrm{S}]$ ) and micronutrients (copper $[\mathrm{Cu}]$, zinc $[\mathrm{Zn}]$, manganese $[\mathrm{Mn}]$, sodium [Na], boron [B], and molybdenum [Mo]) (method 3051A from U. S. EPA 2007) was also carried out. Normative instruction No. 7 still requires analysis and stipulates maximum values for thermotolerant coliforms, 
viable helminth eggs and Salmonella sp. in organic fertilizers, soil conditioners and plant substrates. However, given the origin of biochars (vegetable byproducts, coffee industry), these biological analyses were not performed.

All analyses were performed in triplicate, and the average and standard deviations were provided. When the same attribute was obtained by different methods, one-way analysis of variance (ANOVA) was performed by the $\mathrm{F}$ test ( $\mathrm{p} \leq 0.05)$, and when significant differences were observed, the means were compared by the Tukey's test $(\mathrm{p} \leq 0.05)$.

\section{RESULTS AND DISCUSSION}

\section{Water content, WHC and volumetric (bulk) density}

The determination and reporting of the water content of a biochar is a requirement by the Brazilian NI No. 61 from MAPA, which sets a maximum water content of $40 \%(\mathrm{~m} / \mathrm{m})$ for simple organic fertilizers. Both biochars investigated in the present work, produced from spent coffee grounds and coffee parchment, had water contents well below $40 \%$ (Table 2). The low water content in biochars is due to water evaporation during the pyrolysis process (Cai and Liu 2007), and such characteristics are desirable to facilitate transport and handling. The drying temperature used for the determination of the water content is related to the purposes of the norms. The Brazilian directives NI No. 61 (Brazil 2020) and NI No. 5 (Brazil 2016a) set a drying temperature standard of $65^{\circ} \mathrm{C}$ to avoid $\mathrm{N}$ losses by volatilization during drying. This is not a problematic question for biochars since these materials are produced by pyrolysis and thus should not contain significant concentrations of nutrients in organic form that can be lost by volatilization.

Table 2. Mean values for the moisture, water holding capacity and volumetric (bulk) density for the two evaluated biochars.

\begin{tabular}{|c|c|c|c|}
\hline \multirow{3}{*}{ Biochar } & ${ }^{1}$ Moisture & ${ }^{2} \mathrm{WHC}$ & ${ }^{3}$ Bulk density \\
\hline & $65^{\circ} \mathrm{C}$ & $1 \mathrm{kPa}$ & dry basis \\
\hline & \multicolumn{2}{|c|}{$\longrightarrow(\mathrm{m} / \mathrm{m})$} & $\mathbf{k g} \cdot \mathbf{m}^{-3}$ \\
\hline SCG & $1.3 \pm 0.2$ & $74.2 \pm 2.6$ & $372.0 \pm 20.0$ \\
\hline $\mathrm{CP}$ & $3.6 \pm 0.3$ & $151.9 \pm 6.9$ & $146.0 \pm 5.0$ \\
\hline
\end{tabular}

SCG $=$ spent coffee grounds. $\mathrm{CP}=$ coffee parchment. $\mathrm{WHC}=$ water holding capacity. ${ }^{1} \mathrm{MAPA}\left(\mathrm{NI}\right.$ No. 5; and 61). ${ }^{2,3} \mathrm{MAPA}(\mathrm{NI}$ No. 35).

Note. Numbers after \pm signal indicate the standard deviation $(n=3)$.

The water holding capacity is a physicochemical parameter required by NI No. 35 from MAPA (Brazil 2006) for soil conditioner characterization, and it was determined using an applied pressure (tension) of $1.0 \mathrm{kPa}$, corresponding to a $10 \mathrm{~cm}$ column of water. The mean WHC values obtained were 74.3 and $151.9 \%(\mathrm{~m} / \mathrm{m})$ for the SCG and CP biochars, respectively (Table 2). Normative instruction No. 35 from MAPA (Brazil 2006) sets a minimum value of $60 \%(\mathrm{~m} / \mathrm{m})$ for the WHC of agricultural soil conditioners. Therefore, the two evaluated biochars meet this requirement to be used as soil conditioners in Brazil. It is well reported in the literature that biochar has the capacity to improve soil water retention (Chen et al. 2018), mainly because of its porous structure, which adds inter- and intrapores into the soil, increasing water storage (Liu et al. 2017). Edeh et al. (2020) reported that the addition of biochar increases the available water content by an average of $28.5 \%$ and the field capacity by $20.4 \%$ in soils. Thus, for agricultural use focused on the increase in soil water stock, WHC determination on biochar is an important attribute to consider.

Declaration of the bulk density is a requirement of NI No. 5 from MAPA (Brazil 2016a) for plant substrates. For this purpose, density is an indispensable parameter for the management of irrigation, the selection and addition rates of nutrients, and the identification of suitable containers to grow plants. Smaller containers require lower density substrates to provide the best conditions for plant root system development and consequently crop yields (Fermino and Kämpf 2012). For this purpose, although the NI does not set a limit value, CP biochar would be preferred over SCG as a plant substrate because of its significantly lower bulk density (Table 2). 


\section{$\mathrm{pH}$ and EC}

The determination and reporting of biochar $\mathrm{pH}$ are required by the Brazilian NI No. 5 and No. 61 from MAPA, and there are differences in the extraction solvent according to the methodology (Table 3). For the determination of biochar $\mathrm{pH}, 0.01 \mathrm{~mol} \cdot \mathrm{L}^{-1} \mathrm{CaCl}_{2}$ was used as the extraction solvent, and the $\mathrm{pH}$ values of the extracts were lower than that of water for both biochars. The use of an electrolyte solution, $0.01 \mathrm{~mol} \cdot \mathrm{L}^{-1} \mathrm{CaCl}_{2}$, as the extractor is meant to reduce variability produced by the presence of soluble salts in the material, which consequently results in slightly more acidic pH (Sing et al. 2017).

Table 3. Mean values for $\mathrm{pH}$ and electrical conductivity of the two evaluated biochars.

\begin{tabular}{cccc}
\hline & & pH & \multicolumn{2}{c}{ Electrical conductivity } \\
\cline { 2 - 4 } & & & ratio (1:5) \\
\cline { 2 - 4 } & ${ }^{1}$ Water & ${ }^{2} \mathbf{C a C l}_{2}$ & ${ }^{\mathbf{1}} \mathbf{d S} \cdot \mathbf{m}^{-1}$ \\
\hline SCG & $9.4 \pm 0.1 \mathrm{a}$ & $8.5 \pm 0.1 \mathrm{~b}$ & $0.79 \pm 0.1$ \\
\hline CP & $9.5 \pm 0.1 \mathrm{a}$ & $9.1 \pm 0.1 \mathrm{~b}$ & $8.91 \pm 0.3$ \\
\hline
\end{tabular}

$\mathrm{SCG}=$ spent coffee grounds. $\mathrm{CP}=$ coffee parchment. ${ }^{1} \mathrm{MAPA}\left(\mathrm{NI}\right.$ No. 5). ${ }^{2} \mathrm{MAPA}(\mathrm{NI}$ No. 61). Numbers after \pm signal indicate the standard deviation $(\mathrm{n}=3)$. Lowercase letters accompanying the values in the rows of results indicate significant differences for $\mathrm{pH}(\mathrm{p} \leq 0.05)$.

In all cases, the aqueous extracts obtained from both coffee residue biochars were alkaline. At a high pyrolysis temperature $\left(700{ }^{\circ} \mathrm{C}\right)$ of biomass, some of the elements, namely carbon $(\mathrm{C})$, hydrogen $(\mathrm{H})$, oxygen $(\mathrm{O})$, and $\mathrm{N}$, are lost through the volatilization of organic compounds, so alkaline elements $\mathrm{Na}, \mathrm{Ca}$, and $\mathrm{Mg}$ in the biochar become concentrated and are transformed into their oxides, hydroxides, and carbonates. These, in turn, are constituents of the ash present in biochars and contribute to the alkalinity of these materials (Silva et al. 2021). Considering that Brazilian soils are predominantly acidic (Quaggio 2000), biochar alkalinity can act as lime and increase soil pH (Singh et al. 2017). However, to define the application of coffee residue biochars, the desired final soil $\mathrm{pH}$ and the biochar and soil buffering capacities should be considered, since high application rates might alkalinize the soil (Domingues et al. 2020), which causes negative effects on plant nutrition. The use of $0.01 \mathrm{~mol} \cdot \mathrm{L}^{-1} \mathrm{CaCl}_{2}$ as the extractor solution appears to be the most appropriate method for biochar $\mathrm{pH}$ determination since it reduces the effects of soluble salts and consequently minimizes the analytical error in $\mathrm{pH}$ determination and produces more reliable results.

The determination of EC is required by Brazilian legislation, NI No. 5, from MAPA (Brazil 2016a), but no range is defined by these protocols for soil application. High EC values may be problematic for the agricultural use of a residue, as they indicate high levels of soluble salts in the material (Huang et al. 2019) and have the potential to cause soil salinization. The range considered normal for an organic residue destined for agricultural use is between 0.64 and $6.85 \mathrm{dS} \cdot \mathrm{m}^{-1}$ (Melo et al. 2008). For the aqueous extract prepared from the SCG biochar, the EC was low $\left(0.80 \mathrm{dS} \cdot \mathrm{m}^{-1}\right)$ compared to CP biochar (Table 3), which displayed a much higher EC $\left(8.91 \mathrm{dS} \cdot \mathrm{m}^{-1}\right)$. Nevertheless, a 1:5 ratio is not indicated for calcareous materials because of the influence of salts. Therefore, considering the alkalinity of biochar, probably caused by the concentration of salts, adopting a broader ratio (1:10 or 1:20) could be more appropriate for adapting the current legislation or for the elaboration of a specific biochar legislation.

\section{Elemental contents and CEC}

The $\mathrm{C}$ content is a fundamental parameter of any material of organic origin, and its determination and reporting are required by Brazilian legislation (Table 4). Brazilian legislation from MAPA is focused on organic materials for soil application, aiming to provide $\mathrm{N}$ to plants and improve the soil CEC, so only the determination and reporting of the organic $\mathrm{C}$ content is required. The minimum value for the OC content of $15 \%$ is specified for NI No. 61 from MAPA (Brazil 2020). Both SCG and CP showed OC contents above the specified minimum values and may be classified as biochar suitable for agricultural use (Table 4). 
Table 4. Mean values for organic carbon and nitrogen, cation exchange capacity and stability indicator.

\begin{tabular}{|c|c|c|c|c|}
\hline \multirow{2}{*}{ Biochar } & ${ }^{1} \mathrm{OC}$ & ${ }^{1}$ Total N & \multirow{2}{*}{$\begin{array}{c}{ }^{1} \mathrm{CEC} \\
\mathrm{mmol}_{\mathrm{c}} \cdot \mathrm{kg}^{-1}\end{array}$} & \multirow{2}{*}{$\begin{array}{l}{ }^{1} \mathrm{CEC} / \mathrm{OC} \\
\mathrm{mol}_{\mathrm{c}} \cdot \mathrm{kg}^{-1}\end{array}$} \\
\hline & 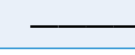 & 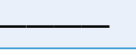 & & \\
\hline SCG & $31.9 \pm 0.8$ & $1.69 \pm 0.0$ & $41.3 \pm 2.4$ & $0.13 \pm 0.1$ \\
\hline $\mathrm{CP}$ & $38.5 \pm 1.8$ & $1.55 \pm 0.1$ & $51.8 \pm 12.1$ & $0.13 \pm 0.1$ \\
\hline
\end{tabular}

$\mathrm{SCG}=$ spent coffee grounds. $\mathrm{CP}=$ coffee parchment. $\mathrm{OC}=$ organic carbon. $\mathrm{CEC}=$ cation exchange capacity. ${ }^{1} \mathrm{MAPA}$ (NI No. 61 ).

Note. Numbers after \pm signal indicate the standard deviation $(n=3)$.

Biochar, nonetheless, differs from other organic materials, as they present higher concentrations of aromatic $\mathrm{C}$, which, in conjunction with surface carboxyl groups, increase the retention of nutrients. Consequently, their application to soils improves agricultural productivity (Rehman and Razzaq 2017), and the presence of aromatic C in biochars stabilizes C and improves its persistence in soils (Sohi et al. 2010). The application of C-containing materials that are resistant to decomposition in soils leads to $\mathrm{C}$ sequestration, removing it from the atmospheric cycle and might help mitigate anthropogenic emissions of $\mathrm{CO}_{2}$ (Ronsse et al. 2013). Thus, these considerations suggest that the determination of total $\mathrm{C}$ beyond the OC should be included in an adaptation to the current legislation or in future Brazilian legislation for the production, use and commercialization of biochars, regardless of a specific intended use.

Nitrogen is one of the most important macronutrients and is present in many of the substances essential to plant metabolism, such as amino acids, proteins, and enzymes; thus, it is vital to crop growth and development. Analyses for this element in organic fertilizers are a requirement of NI No. 61 (Brazil 2020), and for C, the focus on the analyses is on the levels of available $\mathrm{N}$ to plants. This normative specifies a minimum $\mathrm{N}$ content of $0.5 \%(\mathrm{~m} / \mathrm{m})$ (dry mass basis) for all types of organic fertilizer, whose limit is lower than the values found for the two evaluated biochars (Table 4), in such a way that both met the respective Brazilian legislation standards.

Although it is an important nutrient, studies have demonstrated that biochar is not an effective source of $\mathrm{N}$ for promoting plant growth (Chan et al. 2007) and may reduce $\mathrm{N}$ mineralization in soils, hence decreasing the availability of this nutrient (Dempster et al. 2012). In comparison to feedstock biomass, $\mathrm{N}$ loss occurs during pyrolysis, and the remaining $\mathrm{N}$ in biochar is recalcitrant and not readily available to plants (McBeath et al. 2015). However, the application of biochar to agricultural soils can produce modifications that are beneficial to the retention and bioavailability of $\mathrm{N}^{2}$ added as $\mathrm{NH}_{4}^{+}$and $\mathrm{NO}_{3}^{-}$(Zheng et al. 2013), as well as reduced emissions of the greenhouse gas $\mathrm{N} 2 \mathrm{O}$ (Liu et al. 2019). The effects that the application of biochar produces on the soil and crops are characteristics not only of the original biomass and the pyrolysis conditions, but also of the properties of the soil and the local climatic conditions (Ding et al. 2016). Thus, further consideration, as part of the revision of Brazilian legislation, will need to focus on the intended agricultural use of biochar and require more data on how the $\mathrm{N}$ content of biochar influences its characteristics.

The determination of the CEC is required by Ni No. 35 from MAPA (Brazil 2006) for the characterization of organic materials to be used as soil conditioners in Brazil. The official experimental method from MAPA for soil conditioners, which encompasses biochar, can be found in MAPA NI No. 17 (Brazil 2007). The exchange sites in the conditioner are first saturated with $\mathrm{H}^{+}$derived from $0.5 \mathrm{~mol} \cdot \mathrm{L}^{-1} \mathrm{HCl}$, and the $\mathrm{H}^{+}$adsorbed into the exchange sites is then displaced with $0.5 \mathrm{~mol} \cdot \mathrm{L}^{-1}$ calcium acetate, forming acetic acid, which is determined by titration against a standardized $0.1 \mathrm{~mol} \cdot \mathrm{L}^{-1}$ solution of sodium hydroxide. Interest in the CEC of organic materials comes from an established direct relationship between soil productivity and soil CEC. The CEC contribution from organic materials is particularly important for the soils of tropical regions, where organic matter is responsible for up to $80 \%$ of the CEC in the soils (Pacheco and Petter 2011).

For soil conditioners, the minimum CEC required by NI No. 35 of MAPA (Brazil 2006) is $200 \mathrm{mmol}_{\mathrm{c}} \cdot \mathrm{kg}^{-1}$. The CEC values obtained for the SCG and CP biochars were 41.3 and $51.8 \mathrm{mmol}_{\mathrm{c}} \mathrm{kg}^{-1}$, respectively (Table 4). Thus, neither of the biochars evaluated in the present study would be approved for use in Brazil as products for the improvement of the physical or physicochemical properties of a soil. These values are close to the $55.6 \mathrm{mmol} \cdot \mathrm{kg}^{-1}$ found by Silva et al. (2021) for coffee ground biochar but are considerably lower than the $225.4 \mathrm{mmol}_{\mathrm{c}} \mathrm{kg}^{-1}$ verified by the same authors for coffee husk biochar. Both biochars evaluated by Silva et al. (2021) were pyrolyzed at $560^{\circ} \mathrm{C}$, and the CEC was obtained by compulsive exchange by $\mathrm{BaCl}_{2}$ and $\mathrm{MgSO}_{4}$. Andrade et al. (2015) evaluated the $\mathrm{CEC}$ of biochar obtained from the pyrolysis of poultry litter by both the official MAPA method and an alternative method in which $\mathrm{NH}_{4}^{+}\left(\right.$instead of $\left.\mathrm{H}^{+}\right)$from a solution of ammonium 
acetate was utilized as the indicator cation. The adsorbed $\mathrm{NH}_{4}{ }^{+}$was subsequently displaced by ion exchange for $\mathrm{Ca}^{2+}$ from a solution of calcium acetate and determined to be $\mathrm{NH}_{3}$ by distillation. Changing the indicator ion from $\mathrm{H}^{+}$to $\mathrm{NH}_{4}^{+}$was found to increase the result obtained for the CEC of poultry litter-derived biochar by a factor of 2.45 , bringing the value closer to those reported from ammonium-based determinations for other biochars of the same origin.

Graber et al. (2017) initiated attempts to develop a standard method for the determination of the CEC of biochar. In their method, the indicator ion was $\mathrm{NH}_{4}^{+}$, which was loaded into the ion-exchange sites of biochar from a $1 \mathrm{~mol} \cdot \mathrm{L}^{-1} \mathrm{pH} 7$ solution of ammonium acetate, and, after washing the $\mathrm{NH}_{4}^{+}$-saturated biochar with isopropanol, the adsorbed $\mathrm{NH}_{4}^{+}$was subsequently displaced with $\mathrm{KCl} 2 \mathrm{~mol} \cdot \mathrm{L}^{-1}$ and determined to be $\mathrm{NH}_{3}$ by distillation. In general, it has been proven difficult to obtain reproducible results for the CEC of biochar, and Graber et al. (2017) have indicated that heterogeneity, variable porosity, and hydrophobicity are some of the biochar characteristics that hinder reliable CEC determinations.

Munera-Echeverri et al. (2018) continued efforts to explore and resolve the challenges in CEC determination of biochar and indicated the need for various modifications to the Graber et al. (2017) method, including pretreatment of alkaline biochar with $\mathrm{HCl} 0.05 \mathrm{~mol} \cdot \mathrm{L}^{-1}$ to reduce the $\mathrm{pH}$ to 7 and to remove soluble cations to improve reproducibility. Additional studies with a broader variety of different biochars are necessary to establish a single analytical protocol able to produce a reliable and reproducible CEC for any biochar. The challenge is great due to the variable chemical composition and complex supporting matrices of biochars. It should be stressed that the CEC is a property worth determining reliably, since it is affected by the type of feedstock biomass and the pyrolysis temperature (Andrade et al. 2015; Singh et al. 2010), and it is important to assess the potential agricultural uses of biochar. However, as reported above, it is not clear which method would offer more consistent results for a wide range of biochars.

Declaration of the CEC and CEC/OC ratio is required by NI No. 61 from MAPA (Brazil 2020) for the characterization of organic fertilizers (Table 4). The CEC/OC ratio is an indicator of the degree of maturation of organic materials (Dores-Silva et al. 2011) and might indicate the fate and stability of biochar, i.e., higher values of the CEC/OC ratio indicate greater stability.

\section{Macro- and micronutrients}

The application of biochar, which contains macro- and/or micronutrients found in agricultural soils, presents great potential for improving soil fertility and acts as a nutrient source to crops (Ding et al. 2016). Although the legislation addressed in this paper does not require the determination of macronutrient levels (in addition to $\mathrm{N}$ ), the semitotal levels (EPA 3051a method; U.S. EPA 2007) of biochar were evaluated (Table 5). Notably, among the macronutrient results is a high level of $\mathrm{K}(\sim 5 \%[\mathrm{~m} / \mathrm{m}])$ found in the $\mathrm{CP}$ biochar (Table 5). Considering the importance of $\mathrm{K}$ for plant production, the low level of $\mathrm{K}$ in tropical soils (Steiner and Lana 2018) and the fact that $\mathrm{KCl}$ (potassium chloride) is the main source of $\mathrm{K}$ (Prakash and Verma 2016), the application of organic materials with high levels of K, such as $\mathrm{CP}$ biochar, as a complement could be interesting and informative. The Ca content found for the SCG biochar is also noteworthy, as its content may be related to the formation of $\mathrm{CaCO}_{3}$ (calcium carbonate), which, in turn, contributes to neutralizing soil acidity and makes Ca available for absorption by plants (Chintala et al. 2014; Cole et al. 2019).

Table 5. Nutrients and essential elements obtained for the evaluated biochars.

\begin{tabular}{|c|c|c|c|c|}
\hline \multirow{2}{*}{ Biochar } & $\mathbf{P}$ & $\mathbf{K}$ & $\mathbf{S}$ & $\mathrm{Ca}$ \\
\hline & \multicolumn{4}{|c|}{$\longrightarrow \mathrm{g} \cdot \mathrm{kg}^{-1} \longrightarrow$} \\
\hline SCG & $1.6 \pm 0.3$ & $2.7 \pm 0.1$ & $4.6 \pm 0.8$ & $40.0 \pm 3.5$ \\
\hline $\mathrm{CP}$ & $1.5 \pm 0.2$ & $55.1 \pm 1.4$ & $0.8 \pm 0.1$ & $4.6 \pm 0.1$ \\
\hline \multirow{2}{*}{ Biochar } & Mg & Mo & B & $\mathrm{Na}$ \\
\hline & $\mathbf{g} \cdot \mathbf{k g}^{-1}$ & \multicolumn{3}{|c|}{$\longrightarrow \mathrm{mg} \cdot \mathrm{kg}^{-1} \longrightarrow$} \\
\hline SCG & $1.9 \pm 0.1$ & $41.0 \pm 1.0$ & $19.2 \pm 0.5$ & $2144 \pm 1.0$ \\
\hline $\mathrm{CP}$ & $1.4 \pm 0.3$ & $<1.3$ & $41.7 \pm 1.7$ & $50.5 \pm 0.1$ \\
\hline
\end{tabular}

$\overline{\mathrm{SCG}}=$ spent coffee grounds; $\mathrm{CP}=$ coffee parchment; $<=$ Lower than the limit detectable of the equipment; $\mathrm{P}=$ phosphorus; $\mathrm{K}=$ potassium; $\mathrm{S}=$ sulfur; $\mathrm{Ca}=$ calcium; $\mathrm{Mg}=$ magnesium; $\mathrm{Mo}=$ molybdenum; $\mathrm{B}=$ boron; $\mathrm{Na}=$ sodium.

Note. Numbers after \pm signal indicate the standard deviation $(n=3)$. 
Given the global importance of nutrients for soil improvement and food production, the determination of macro- and micronutrients should be included in future specific legislation for biochars if their intended use is fertilizer. Although the semitotal content extracted by nitric acid may not represent the amount available to plants, this content can be used as an indicator for choosing adequate biochar (Ding et al. 2016).

\section{Potentially toxic metals and inert materials}

In addition to macronutrients, the contents of micronutrients and potentially toxic metals were evaluated in biochar. Determinations were performed for the total content of the following metallic and metalloid elements: $\mathrm{Ni}, \mathrm{Cu}, \mathrm{Zn}, \mathrm{Se}$, $\mathrm{Cd}, \mathrm{Pb}, \mathrm{Cr}, \mathrm{Hg}$ and $\mathrm{As}$ (Table 6), which are widely regulated due to the hazards they present to the health of animals and plants. When present in soil, even at low concentrations, these elements may be absorbed by roots, translocated through the plant, stored and accumulated in tissues and grains. As mentioned for alkaline cations, after pyrolysis, the metallic content is concentrated in the biochar, whose final content will vary depending on the biomass used for the production of biochar. Therefore, for the safe agricultural use of biochars, these elements must be investigated. As noted previously, there is no specific Brazilian legislation for biochar. Thus, the limits of potentially toxic elements must be in accordance with NI No. 7 from MAPA (Brazil 2016b) for agricultural use. Materials to be used as organic fertilizers and soil conditioners are distinguished from materials to be used as plant substrates in NI No. 7.

Table 6. Micronutrient, potentially toxic metal and inert material contents obtained for the evaluated biochars.

\begin{tabular}{|c|c|c|c|c|}
\hline \multirow{4}{*}{ Elements } & \multicolumn{2}{|c|}{ Biochar } & \multirow{2}{*}{\multicolumn{2}{|c|}{$\begin{array}{c}\text { MAPA(NI No. 7) } \\
{ }^{1} \text { Maximum permitted level }\end{array}$}} \\
\hline & \multirow{2}{*}{ SCG } & \multirow{2}{*}{$\mathrm{CP}$} & & \\
\hline & & & A & B \\
\hline & \multicolumn{4}{|c|}{$\longrightarrow \mathrm{mg} \cdot \mathrm{kg}^{-1} \leftrightharpoons$} \\
\hline $\mathrm{Ni}$ & $216.3 \pm 13.7$ & $5.6 \pm 1.1$ & 70 & 175 \\
\hline $\mathrm{Cu}$ & $208.5 \pm 5.5$ & $22.4 \pm 1.6$ & ni & ni \\
\hline $\mathrm{Zn}$ & $184.5 \pm 1.5$ & $11.3 \pm 0.7$ & ni & ni \\
\hline $\mathrm{Se}$ & $<1.0$ & $<1.1$ & 80 & 80 \\
\hline $\mathrm{Cd}$ & $0.5 \pm 0.1$ & $<0.2$ & 3.0 & 8.0 \\
\hline $\mathrm{Pb}$ & $5.2 \pm 0.2$ & $<2.9$ & 150 & 300 \\
\hline $\mathrm{Cr}$ & $44.5 \pm 12.5$ & $<0.3$ & ni & 500 \\
\hline $\mathrm{Cr}^{6+}$ & $<1.4$ & $<1.4$ & 2.0 & ni \\
\hline $\mathrm{Hg}$ & $<1.0$ & $<1.0$ & 1.0 & 2.5 \\
\hline As & $<1.0$ & $<1.0$ & 20 & 20 \\
\hline Inert materials & \multicolumn{4}{|c|}{ — dry basis } \\
\hline $\begin{array}{l}\text { Glass, plastic and } \\
\text { metals (>2 mm) }\end{array}$ & 0.0 & 0.0 & 0.5 & - \\
\hline Stones (> $5 \mathrm{~mm}$ ) & 0.0 & 0.0 & 5.0 & - \\
\hline
\end{tabular}

For the metals $\mathrm{Ni}, \mathrm{Cd}, \mathrm{Pb}, \mathrm{Cr}$, and $\mathrm{Hg}$, the maximum permitted limits in plant substrates are higher than those for organic fertilizers and soil conditioners. The difference is particularly striking for $\mathrm{Cr}$, where for organic fertilizers and soil conditioners, the determination required is $\mathrm{Cr}^{6+}$ against a maximum permitted level of $2 \mathrm{mg} \cdot \mathrm{kg}^{-1}$, while for plant substrates total $\mathrm{Cr}$ is required, with a maximum permitted level of $500 \mathrm{mg} \cdot \mathrm{kg}^{-1}$. Hexavalent chromium compounds are water soluble and are encountered principally in effluents from the electroplating, leather tanning, and pigment industries (Dehghani et al. 2016), and they are highly toxic to plants and animals and carcinogenic to humans. However, in soils and solid organic materials, Cr occurs 
predominantly as $\mathrm{Cr}^{3+}$ compounds, whose properties include low or zero solubility in water, low mobility, and low toxicity to plants, animals, and the environment (Sousa and Santos 2018). This fact was observed for both biochars evaluated in this study, since only the SCG biochar presented a total $\mathrm{Cr}$ content $\left(44.5 \mathrm{mg} \cdot \mathrm{kg}^{-1}\right)$, while the $\mathrm{Cr}^{6+}$ content observed for the biochars was below the detection limit of the method $\left(<1.4 \mathrm{mg} \cdot \mathrm{kg}^{-1}\right)$, which in turn was below the limit stated by the legislation $\left(2 \mathrm{mg} \cdot \mathrm{kg}^{-1}\right)$.

The Ni content of the SCG biochar $\left(216 \mathrm{mg} \cdot \mathrm{kg}^{-1}\right)$ is above the maximum permitted level specified in both guidelines (for organic fertilizers and soil conditioner and for plant substrates), so that in its raw form SCG is unsuitable for agricultural use. It could, however, be mixed with other materials of low $\mathrm{Ni}$ content, such as $\mathrm{CP}$ biochar, to produce an acceptable product. In fact, Ni has been identified as an essential plant micronutrient (Liu 2001), and Ni-bearing biochar, such as SCG, may be used as a corrective for application to Ni-deficient soils. The higher metal content observed in SCG compared to PC, mainly Ni, may be related to the industrial process it was submitted to before pyrolysis as biochar. While $\mathrm{CP}$ is obtained in the initial stages of coffee processing (pulping), SCG is generated after grinding, extraction and drying for soluble coffee production (Blinová et al. 2017). All these processes may contribute to adding trace concentrations of metal, but a concentration effect from the original metal content from the original biomass can be expected in the final waste, which might also contribute to the higher metal content in SCG biochar.

For the other elements for which determinations were made, both evaluated biochars presented contents below the maximum permitted levels specified in any of the guidelines. Considering these results, the Brazilian-adapted legislation for biochar characterization must include guidelines for heavy metal contents in biochar for all agricultural use purposes.

Normative instruction No. 7 from MAPA (Brazil 2016a) also requires the analysis of inert materials for organic fertilizers and soil conditioners and stipulates maximum values by dry mass. The maximum permitted values are $0.5 \%$ for glass, plastics and metals $(>2 \mathrm{~mm}$ ) and $5 \%$ for stones $(>5 \mathrm{~mm}$ ). For both biochars, the content of these materials was not observed (Table 6), which is in accordance with the biomasses used, derived from byproducts of the coffee industry. For the safe use of biochars in agriculture, from production to application, the evaluation of inert material is an important aspect to be considered.

\section{Particle size distribution}

Several benefits of applying biochar to soils have been shown to be linked to their particle sizes. The pores within biochar particles with sizes greater than $0.25 \mathrm{~mm}$ have been demonstrated to play an important role in increasing the water holding capacity of soils (Liu et al. 2017). The NI No. 61 from MAPA (Brazil 2020) provides granulometric specifications for the identification of four textural classes of organic fertilizers: granular, powdered, ground, and coarsely ground. Thus, particle size analysis was performed, and the mass percentage of each class was declared (Table 7). For the SCG biochar, the majority of the particles $(\sim 68 \% \mathrm{~m} / \mathrm{m})$ were $<2 \mathrm{~mm}$, while the proportion by mass with sizes below $2 \mathrm{~mm}$ CP biochar was approximately $20 \%$. Soil-biochar interactions are mediated through surface contact, which is greater for smaller particles (Duarte et al. 2019), which might explain the higher WHC value for SCG biochar than CP biochar. However, small particles are more easily lost during transport and by wind when biochar is applied to and incorporated into soils (Maienza et al. 2017).

Table 7. Particle size distribution of biochars in each class.

\begin{tabular}{|c|c|c|c|c|}
\hline \multirow{3}{*}{ Biochar } & \multicolumn{4}{|c|}{ Mesh of the sieves $(\mathrm{mm})$} \\
\hline & $>4.8$ & $<4.8$ and $>4.0$ & $<4.0$ and $>3.36$ & $<3.36$ and $>2.0$ \\
\hline & \multicolumn{4}{|c|}{ Retained in the sieves (\%) } \\
\hline PGM & $39.0 \pm 3.4$ & $6.6 \pm 0.7$ & $16.5 \pm 3.4$ & $17.9 \pm 1.4$ \\
\hline \multirow[t]{2}{*}{ SCG } & $8.6 \pm 3.1$ & $3.9 \pm 0.3$ & $4.3 \pm 0.3$ & $15.0 \pm 1.3$ \\
\hline & \multicolumn{4}{|c|}{ Mesh of the sieves $(\mathrm{mm})$} \\
\hline \multirow[t]{2}{*}{ Biochar } & $<2.0$ and $>1.0$ & $<1.0$ and $>0.84$ & $<0.84$ and $>0.3$ & $<0.3$ \\
\hline & \multicolumn{4}{|c|}{ Retained in the sieves (\%) } \\
\hline PGM & $10.9 \pm 1.7$ & $2.1 \pm 0.4$ & $6.1 \pm 0.7$ & $0.9 \pm 0.2$ \\
\hline SCG & $19.7 \pm 1.6$ & $5.7 \pm 0.9$ & $30.2 \pm 1.3$ & $12.6 \pm 1.2$ \\
\hline
\end{tabular}

$\mathrm{SCG}=$ spent coffee grounds. $\mathrm{CP}=$ coffee parchment.

Note. Numbers after \pm signal indicate the standard deviation $(n=3)$. 
The particle size distribution results obtained by dry sieving of the two biochars evaluated in the present study did not match any of the MAPA textural classes, and therefore, the biochar would be classified as "products without a granulometric specification" (Brazil 2020, Chapter II, subsection I). Nevertheless, in a proposal for Brazilian regulation, it is important to include a granulometric profile of biochar due its interference in the porosity, WHC, and other characteristics when applied in soil.

\section{CONCLUSION}

Coffee parchment biochar could be used as organic fertilizer and plant substrate but not as a soil conditioner due to its low CEC and SCG biochar. Due to its higher Ni content and lower than required CEC, CP biochar did not meet the Brazilian Ministry of Agriculture, Livestock, and Food Supply (MAPA) legislation requirements to allow for its agricultural use.

The results obtained during this study demonstrate the need for Brazil to bring forward new and specific legislation addressing the characterization, regulation, and commercialization of biochars. Further research may also indicate the viability of biochar as a soil conditioner based on a more representative set of biomasses with a higher CEC. A future regulation can be based on current standards, but it should define all the parameters to be determined, identify reliable methodologies for their determination, and, where appropriate, set minimum or maximum acceptable values. Structural attributes such as total $\mathrm{C}$ content, particle size distribution, and complete macro- and micronutrient determination should be included in this protocol, and WHC must be declared when agricultural use focuses on increasing the soil water stock.

These actions will make possible the employment of biochar by Brazilian farmers in a way that is safe at all stages in the production chain, from biochar production, through field utilization, to the human and animal consumption of agricultural crops raised in biochar-amended soils.

\section{AUTHORS' CONTRIBUTION}

Conceptualization: Carnier R., Coscione A. R. and Abreu C. A.; Methodology: Carnier R., Coscione A. R. and Abreu C. A.; Investigation: Carnier R.; Writing - Original Draft: Carnier R.; Writing - Review and Editing: Carnier R., Coscione A. R., Delaqua D.; Funding Acquisition: Abreu C. A and Coscione A. R.; Resources: Coscione A. R.; Supervision: Coscione A. R.; Data Curation: Carnier R.; Formal Analysis: Carnier R.; Validation: Carnier R.; Visualization: Carnier R., Coscione A. R. and Delaqua D.; Project Administration: Abreu C. A., Coscione A. R.

\section{DATA AVAILABILITY STATEMENT}

All dataset were generated and analyzed in the current study.

\section{FUNDING}

Fundação de Amparo à Pesquisa do Estado de São Paulo

[https://doi.org/10.13039/501100001807]

Grant No. 2016/19368-6

Coordenação de Aperfeiçoamento de Pessoal de Nível Superior

[https://doi.org/10.13039/501100002322]

Finance Code 001 


\section{ACKNOWLEDGMENTS}

Not applicable.

\section{REFERENCES}

Andrade, C. A., Bibar, M. P. S., Coscione, A. R., Pires, A. M. M. and Soares, Á. G. (2015). Mineralização e efeitos de biocarvão de cama de frango sobre a capacidade de troca catiônica do solo. Pesquisa Agropecuária Brasileira, 50, 407-416. https://doi.org/10.1590/ S0100-204X2015000500008

Blinová, L., Sirotiak, M., Bartošová, A. and Soldán, M. (2017). Review: Utilization of waste from coffee production. Research Papers Faculty of Materials Science and Technology Slovak University of Technology, 25, 91-101. https://doi.org/10.1515/rput-2017-0011

[Brazil]. Ministério da Agricultura, Pecuária e Abastecimento. (2006). Instrução Normativa SDA no 35 de 4 de julho de 2006. Art. $1^{\circ}$ Fica aprovada as normas sobre especificações e garantias, tolerâncias, registro, embalagem e rotulagem dos corretivos de acidez, de alcalinidade e de sodicidade e dos condicionadores de solo, destinados à agricultura, na forma do Anexo a esta Instrução Normativa. Art. $2^{\circ} \mathrm{O}$ descumprimento das normas estabelecidas nesta Instrução Normativa, sujeita ao infrator às sanções previstas no Decreto no 4.954, de 2004. Art. $3^{\circ}$ Fica concedido o prazo de noventa dias, da data de sua vigência, para os interessados se adequarem às exigências desta Instrução Normativa. Art. $4^{\circ}$ Esta Instrução Normativa entra em vigor na data de sua publicação. Art. $5^{\circ}$ Revoga-se a Instrução Normativa SARC no 04, de 2 de agosto de 2004. [Accessed October, 21, 2021]. Available at: https://www.gov.br/agricultura/ pt-br/assuntos/insumos-agropecuarios/insumos-agricolas/fertilizantes/legislacao/in-35-de-4-7-2006-corretivos.pdf

[Brazil]. Ministério da Agricultura, Pecuária e Abastecimento. (2007). Instrução Normativa n 17, de 21 de maio de 2007. Art. 1 Aprovar os Métodos Analíticos Oficiais para Análise de Substratos e Condicionadores de Solos, na forma do Anexo à presente Instrução Normativa. Art. $2^{\circ}$ Esta Instrução Normativa entra em vigor na data de sua publicação. Art. 30 Fica revogada a Instrução Normativa no 46 , de 12 de setembro de 2006. [Accessed October, 21, 2021]. Available at: https://www.gov.br/agricultura/pt-br/assuntos/insumos-agropecuarios/ insumos-agricolas/fertilizantes/legislacao/in-17-de-21-05-2007-aprova-metodo-substrato.pdf

[Brazil]. Ministério da Agricultura, Pecuária e Abastecimento. (2016b). Instrução Normativa no 7, de 02 de maio de 2016. Dispõe sobre as concentrações máximas admitidas para agentes fitotóxicos, patogênicos ao homem, animais e plantas, metais pesados tóxicos, pragas e ervas daninhas em fertilizantes, corretivos, inoculantes e biofertilizantes. Brasília: Diário Oficial da União. [Accessed October, 21, 2021]. Available at: https://www.gov.br/agricultura/pt-br/assuntos/insumos-agropecuarios/insumos-agricolas/fertilizantes/legislacao/ in-sda-27-de-05-06-2006-alterada-pela-in-sda-07-de-12-4-16-republicada-em-2-5-16.pdf

[Brazil]. Ministério da Agricultura, Pecuária e Abastecimento. (2016a). Instrução Normativa, no 5 de 10 de março de 2016. Ficam estabelecidas as regras sobre definições, classificação, especificações e garantias, tolerâncias, registro, embalagem e propaganda dos remineralizadores e substratos para plantas, destinados à agricultura. Brasília: Diário Oficial da União. [Accessed October, 21, 2021]. Available at: https://www.in.gov.br/materia/-/asset_publisher/Kujrw0TZC2Mb/content/id/21393137/ do1-2016-03-14-instrucao-normativa-n-5-de-10-de-marco-de-2016-21393106

[Brazil]. Ministério da Agricultura, Pecuária e Abastecimento. (2017). Análise dos fertilizantes orgânicos e organominerais destinados à aplicação via solo, capitulo 3. In Manual de Métodos Analíticos oficiais para fertilizantes e corretivos (p. 137-179). Brasília: Secretaria de Defesa Agropecuária.

[Brazil]. Ministério da Agricultura, Pecuária e Abastecimento. (2020). Instrução Normativa n 61, de 8 de julho de 2020 . Estabelece as regras sobre definições, exigências, especificações, garantias, tolerâncias, registro, embalagem e rotulagem dos fertilizantes orgânicos e dos biofertilizantes, destinados à agricultura. Brasília: Diário Oficial da União. [Accessed October, 21, 2021]. Available at: https://www. in.gov.br/web/dou/-/instrucao-normativa-n-61-de-8-de-julho-de-2020-266802148 
Cai, J. and Liu, R. (2007). Research on water evaporation in the process of biomass pyrolysis. Energy \& Fuels, 21, 3695-3697. https://doi. org/10.1021/ef700442n

Carnier, R., Berton, R. S., Coscione, A. R., Pires, A. M. M. and Corbo, J. Z. F. (2019). Coffee silverskin and expired coffee powder used as organic fertilizers. Coffee Science, 14, 24-32. https://doi.org/10.25186/cs.v14i1.1514

Cervera-Mata, A., Navarro-Alarcón, M., Delgado, G., Pastoriza, S., Montilla-Gómez, J., Llopis, J., Sánchez-González, C. and RufiánHenares, J. A. (2019). Spent coffee grounds improve the nutritional value in elements of lettuce (Lactuca sativa L.) and are an ecological alternative to inorganic fertilizers. Food Chemistry, 282, 1-8. https://doi.org/10.1016/j.foodchem.2018.12.101

Chan, K. Y., Zwieten, L. V., Meszaros, I., Downie, A. and Joseph, S. (2007). Agronomic values of greenwaste biochar as a soil amendment. Australian Journal of Soil Research, 45, 629-634. https://doi.org/10.1071/SR07109

Chen, C., Wang, R., Shang, J., Liu, K., Irshad, M. K., Hu, K. and Arthur, E. (2018). Effect of biochar application on hydraulic properties of sandy soil under dry and wet conditions. Vadose Zone Science, 17, 1-8. https://doi.org/10.2136/vzj2018.05.0101

Chintala, R., Mollinedo, J., Shumacher, T. E., Malo, D. D. and Julson, J. L. (2014). Effect of biochars on chemical properties of acidic soil. Archives of Agronomy and Soil Science, 60, 393-404. https://doi.org/10.1080/03650340.2013.789870

Chwastowski, J., Bradło, D. and Żukowski, W. (2020). Adsorption of cadmium, manganese and lead ions from aqueous solutions using spent coffee grounds and biochar produced by its pyrolysis in the fluidized bed reactor. Materials, 13, 2782. https://doi.org/10.3390/ ma13122782

Cole, E. J., Zandvakili, O. R., Xing, B., Hashemi, M., Barker, A. V. and Herbert, S. J. (2019). Effect of hardwood biochar on soil acidity, nutrient dynamics, and sweet corn productivity. Communications in Soil Science and Plant Analysis, 50, 1732-1742. https://doi.org/10. 1080/00103624.2019.1632343

[Conab] Companhia Nacional de Abastecimento. (2020). Acompanhamento da safra brasileira: Café (Vol. 5, n. 6). Brasília: Conab.

Cornelissen, G., Pandit, N. R., Taylor, P., Pandit, B. H., Sparrevik, M. and Schmidt, H. P. (2016). Emissions and char quality of flame-curtain "Kon Tiki" kilns for farmer-scale charcoal/ biochar production. PLoS ONE, 11, e0154617. https://doi.org/10.1371/journal.pone.0154617

Dehghani, M. H., Sanaei, D., Ali, I. and Bhatnagar, A. (2016). Removal of chromium (VI) from aqueous solution using treated waste newspaper as a low-cost adsorbent: Kinetic modeling and isotherm studies. Journal of Molecular Liquids, 215, 671-679. https://doi. org/10.1016/j.molliq.2015.12.057

Dempster, D. N., Gleeson, D. B., Solaiman, Z. M., Jones, D. L. and Murphy, D. V. (2012). Decreased soil microbial biomass and nitrogen mineralisation with Eucalyptus biochar addition to a coarse textured soil. Plant and Soil, 354, 311-324. https://doi.org/10.1007/ s11104-011-1067-5

Dias, D. R., Valencia, N. R., Franco, D. A. Z. and López-Núñez, J. C. (2014). Management and utilization of wastes from coffee processing. In R. F. Schwan, and G. H. Fleet (Eds.), Cocoa and coffee fermentations (p. 376-382). Boca Raton: CRC Taylor \& Francis.

Ding, Y., Liu, Y., Liu, S., Li, Z., Tan, X., Huang, X., Zeng, G., Zhou, L. and Zheng, B. (2016). Biochar to improve soil fertility: A review. Agronomy for Sustainable Development, 36, 36. https://doi.org/10.1007/s13593-016-0372-Z

Dispenza, V., Pasquale, C., Fascella, G., Mammano, M. M. and Alonzo, G. (2016). Use of biochar as peat substitute for growing substrates of Euphorbia $\times$ lomi potted plants. Spanish Journal of Agricultural Research, 14, e0908.

Domingues, R. R., Sánchez-Monedero, M. A., Spokas, K. A., Melo, L. C. A., Trugilho, P. F., Valenciano, M. N. and Silva, C. A. (2020). Enhancing cation exchange capacity of weathered soils using biochar: Feedstock, pyrolysis conditions and addition rate. Agronomy, 10, 824. https://doi.org/10.3390/agronomy10060824

Dores-Silva, P. R., Landgraf, M. D. and Rezende, M. O. O. (2011). Acompanhamento químico da vermicompostagem de lodo de esgoto doméstico. Química Nova, 34, 956-961. https://doi.org/10.1590/S0100-40422011000600008 
Duarte, S. J., Glaser, B. and Cerri, C. E. P. (2019). Effect of biochar particle size on physical, hydrological and chemical properties of loamy and sandy tropical soils. Agronomy, 9, 165. https://doi.org/10.3390/agronomy9040165

[EBC] European Biochar Certificate. (2012). Guidelines for a sustainable production of biochar. Arbaz: EBC.

Edeh, I. G., Mašek, O. and Buss, W. (2020). A meta-analysis on biochar's effect on soil water properties: New insights and future research challenges. Science of the Total Environment, 714, 136857. https://doi.org/10.1016/j.scitotenv.2020.136857

Fermino, M. H. and Kämpf, A. N. (2012). Densidade de substratos dependendo dos métodos de análise e níveis de umidade. Horticultura Brasileira, 30, 75-79. https://doi.org/10.1590/S0102-05362012000100013

Gabhane, J. W., Bhange, V. P., Patil, P. D., Bankar, S. T. and Kumar, S. (2020). Recent trends in biochar production methods and its application as a soil health conditioner: A review. SN Applied Sciences, 2, 1307. https://doi.org/10.1007/s42452-020-3121-5

Graber, E. R., Singh, B. H. K. and Lehmann, J. (2017). Determination of cation exchange capacity in biochar. In B. Singh, M. CampsArbestain, and J. Lehmann (Eds.), Biochar: A guide to analytical methods (p. 74-84). Australia: CSIRO.

Hardgrove, S. J. and Livesley, S. J. (2016). Applying spent coffee grounds directly to urban agriculture soils greatly reduces plant growth. Urban Forestry \& Urban Greening, 18, 1-8. https://doi.org/10.1016/j.ufug.2016.02.015

Huang, M., Zhang, Z., Zhai, Y., Lu, P. and Zhu, C. (2019). Effect of straw biochar on soil properties and wheat production under saline water irrigation. Agronomy, 9, 457. https://doi.org/10.3390/agronomy9080457

Hussain, M., Farooq, M., Nawaz, A., Al-Sadi, A. M., Solaiman, Z. M., Alghamdi, S. S., Ammara, U., Ok, Y. S. and Siddique, K. H. M. (2017). Biochar for crop production: Potential benefits and risks. Journal of Soils and Sediments, 17, 685-716. https://doi.org/10.1007/s11368-016-1360-2

[IBI] International Biochar Initiative. (2015). Standardized product definition and product testing guidelines for biochar that is used in soil. Canandaigua: IBI.

Jeyasubramanian, K., Thangagiri, B., Sakthivel, A., Raja, J. D., Seenivasan, S., Vallinayagam, P., Madhavan, D., Devi, S. M., Rathika, B. (2021). A complete review on biochar: Production, property, multifaceted applications, interaction mechanism and computational approach. Fuel, 292, 120243. https://doi.org/10.1016/j.fuel.2021.120243

Kamau, S., Karanja, N. K., Ayuke, F. O. and Lehmann, J. (2019). Short-term influence of biochar and fertilizer-biochar blends on soil nutrients, fauna and maize growth. Biology and Fertility of Soils, 55, 661-673. https://doi.org/10.1007/s00374-019-01381-8

Lehmann, J. and Joseph, S. (2015). Biochar for environmental management: An introduction. In J. Lehman, and S. Joseph (Eds.), Biochar for environmental management: Science, technology and implementation (p. 1-13). London: Taylor \& Francis.

Lin, Q., Xu, X., Wang, L., Chen, Q., Fang, J., Shen, X., Lou, X. and Tian, G. (2017). The speciation, leachability and bioaccessibility of Cu and $\mathrm{Zn}$ in animal manure-derived biochar: Effects of feedstock and pyrolysis temperature. Frontiers of Environmental Science \& Engineering, 11, 5. https://doi.org/10.1007/s11783-017-0924-8

Liu, G. D. (2001). A new essential mineral element: Nickel. Plant Nutrition and Fertilizer Science, 7, 101-103.

Liu, X., Mao, P., Li, L. and Ma, J. (2019). Impact of biochar application on yield-scaled greenhouse gas intensity: A meta-analysis. Science of the Total Environment, 656, 969-976. https://doi.org/10.1016/j.scitotenv.2018.11.396

Liu, Z., Dungan, B., Masiello, C. A. and Gonnermann, H. M. (2017). Biochar particle size, shape, and porosity act together to influence soil water properties. PLoS ONE, 12, e0179079. https://doi.org/10.1371/journal.pone.0179079

Magalhães, W. L. E., Matos, M. and Rodrigues, L. F. (2018). Processo agroindustrial: Produção de fertilizante organomineral a partir de finos de carvão de pirolise rápida [Comunicado técnico 428]. Guaraituba: Embrapa Florestas.

Maienza, A., Genesio, L., Acciai, M., Miglietta, F., Pusceddu, E. and Vaccari, F. P. (2017). Impact of biochar formulation on the release of particulate matter and on short-term agronomic performance. Sustainability, 9, 1131. https://doi.org/10.3390/su9071131 
Manzano, R., Diquattro, S., Roggero, P. P., Pinna, M. V., Garau, G. and Castaldi, P. (2020). Addition of softwood biochar to contaminated soils decreases the mobility, leachability and biocaccesibility of potencially toxic elements. Science of The Total Environment, 739 , 139946. https://doi.org/10.1016/j.scitotenv.2020.139946

Martins Filho, A. P., Medeiros, E. V., Lima, J. R. S., Duda, G. P., Silva, W. M., Antonino, A. C. D., Silva, J. S. A., Oliveira, J. B. and Hammecker, C. (2020). Impact of coffee biochar on soil carbon, microbial biomass and enzymatic activities in semiarid sand soil cultivated with maize. Revista Brasileira de Geografia Física, 13, 903-914. https://doi.org/10.26848/rbgf.v13.3.p903-914

McBeath, A. V., Wurster, C. M. and Bird, M. I. (2015). Influence of feedstock properties and pyrolysis conditions on biochar carbon stability as determined by hydrogen pyrolysis. Biomass and Bioenergy, 73, 155-173. https://doi.org/10.1016/j.biombioe.2014.12.022

Melo, L. C. A., Silva, C. A. and Dias, B. O. (2008). Caracterização da matriz orgânica de resíduos de origens diversificadas. Revista Brasileira de Ciência do Solo, 32, 101-110. https://doi.org/10.1590/S0100-06832008000100010

Munera-Echeverri, J. L., Martinsen, V., Strand, L. T., Zivanovic, V., Cornelissen, G. and Mulder, J. (2018). Cation exchange capacity of biochar: An urgent method modification. Science of the Total Environment, 642, 190-197. https://doi.org/10.1016/j.scitotenv.2018.06.017

Nelson, D. W. and Sommers, L. E. (1996). Total carbon, organic carbon, and organic matter. In D. L. Sparks, A. L. Page, P. A. Helmke, R. H. Loeppert, P. N. Soltanpour, M. A. Tabatabai, C. T. Johnston and M. E. Summer (Eds.), Methods of soil analysis: Chemical methods (Part 3, p. 961-1010). Madison: Soil Science of America and American Society of Agronomy.

Pacheco, L. P., Petter, F. A. (2011). Benefits of cover crops in soybean plantation in Brazilian cerrados. In T.-B. Ng (Eds.), Soybean: Applications and technology (p. 67-94). IntechOpen. https://doi.org/10.5772/15675

Prakash, S. and Verma, J. P. (2016). Global perspective of potash for fertilizer production. In V. S. Meena., B. R. Maurya., J. P. Verma and R. S. Meena (Eds.), Potassium solubilizing microorganisms for sustainable agriculture (p. 327-331). New Delhi: Springer. https://doi. org/10.1007/978-81-322-2776-2_23

Quaggio, J. A. (2000). Acidez e calagem em solos tropicais. Campinas: Instituto Agronômico.

Rehman, H. A. and Razzaq, R. (2017). Benefits of biochar on the agriculture and environment: A review. Journal of Environmental Analytical Chemistry, 4, 1000207. https://doi.org/10.4172/2380-2391.1000207

Ronsse, F., van Hecke, S., Dickinson, D. and Prins, W. (2013). Production and characterization of slow pyrolysis biochar: Influence of feedstock type and pyrolysis conditions. Global Change Biology Bioenergy, 5, 104-115. https://doi.org/10.1111/gcbb.12018

Sá, I. P., Souza, G. B. and Nogueira, A. R. A. (2021). Chromium speciation in organic fertilizer by cloud point extraction and optimization through experimental Doehlert design as support for legislative aspects. Microchemical Journal, 160, 105618. https://doi.org/10.1016/j. microc. 2020.105618

Shaaban, A., Se, S.-M., Mitan, N. M. M. and Dimin, M. F. (2013). Characterization of biochar derived from rubber wood sawdust through slow pyrolysis on surface porosities and functional groups. Procedia Engineering, 68, 365-371. https://doi.org/10.1016/j.proeng.2013.12.193

Silva, C. C. G., Medeiros, E. V., Fracetto, G. G. M., Fracetto, F. J. C., Martins Filho, A. P., Lima, J. R. S., Duda, G. P., Costa, D. P., Lira Junior, M. A. and Hemmecker, C. (2021). Coffee waste as an eco-friendly and low-cost alternative for biochar production impacts on sandy soil chemical attributes and microbial gene abundance. Bragantia, 80, e2121.

Silva, V. L., Belém, R. S., Marimon Junior, B. H., Andrade, F. R., Farias, J. and Rocha, N. C. L. (2018). Biochar como condicionante de solo no cultivo do eucalipto híbrido urograndis. Scientific Electronic Archives, 11, 7-13.

Singh, B., Camps-Arbestain, M. and Lehmann, J. (2017). Biochar: A guide to analytical methods. Australia: CSIRO. https://doi. org/10.1071/9781486305100

Singh, B., Singh, B. P. and Cowie, A. L. (2010). Characterization and evaluation of biochars for their application as a soil amendment. Australian Journal of Soil Research, 48, 516-525. https://doi.org/10.1071/SR10058 
Sohi, S. P., Krull, E., Lopez-Capel, E. and Bol, R. (2010). A review of biochar and its use and function in soil. Advances in Agronomy, 105, 47-82. https://doi.org/10.1016/S0065-2113(10)05002-9

Soulaïmana, A., Kassi, F., Lezin, B. E., Lazare, N. K., Yao, A. R. and Séverin, A. (2019). Potential use of coffee bean parchment as substrate for soilless tomato (Solanum lycopersicum L.) cultivation in Gabon. International Journal of Sciences, 8, 58-67. https://doi.org/10.18483/ ijSci.2178

Sousa, V. F. O. and Santos, G. L. (2018). Elemento cromo na nutrição mineral de plantas. Revista da Universidade Vale do Rio Verde, 16, 1-7. https://doi.org/10.5892/ruvrd.v16i2.4352

Steiner, F. and Lana, M. C. (2018). Contribution of non-exchangeable K in soils from southern Brazil under potassium fertilization and successive cropping. Revista Ciência Agronômica, 49, 547-557. https://doi.org/10.5935/1806-6690.20180062

[U.S. EPA] United States Environmental Protection Agency. (2007). U.S. EPA Method 3051A (SW-846): Microwave assisted acid digestion of sediments, sludges, and oils, Revision 1. Washington: U.S. EPA. [Accessed Aug. 1, 2018]. Available at: https://www.epa. gov/homeland-security-research/us-epa-method-3051a-microwave-assisted-acid-digestion-sediments-sludges

Zhao, B., O'Connor, D., Zhang, J., Peng, T., Shen, T., Tsang, D. C. W. and Hou, D. (2018). Effect of pyrolysis temperature, heating rate, and residence time on rapeseed stem derived biochar. Journal of Cleaner Production, 174, 977-987. https://doi.org/10.1016/j.jclepro.2017.11.013 Zheng, H., Wang, Z., Deng, X., Herbert, S. and Xing, B. (2013). Impacts of adding biochar on nitrogen retention and bioavailability in agricultural soil. Geoderma, 206, 32-39. https://doi.org/10.1016/j.geoderma.2013.04.018 